\title{
SOCIAL RESPONSIBILITY, AN ESSENTIAL STRATEGIC OPTION FOR A SUSTAINABLE DEUELOPMENT IN THE FIELD OF BIO-ECONOMY
}

\author{
Armenia Androniceanu ${ }^{1 *}$ \\ 1) Bucharest University of Economic Studies, Bucharest, Romania.
}

\begin{tabular}{|l|l|}
\hline Please cite this article as: & Article History \\
Androniceanu, A., 2019. Social Responsibility, an & Received: 23 February 2019 \\
Essential Strategic Option for a Sustainable & Revised: 16 May 2019 \\
Development in the Field of Bio-Economy. Amfiteatru & Accepted: 2 July 2019 \\
Economic, 21(52), pp. 503-519. & \\
DOI: $\mathbf{1 0 . 2 4 8 1 8 / E A / 2 0 1 9 / 5 2 / 5 0 3}$ & \\
\hline
\end{tabular}

\begin{abstract}
Globalization determines the economic environment to identify new development models that harmoniously integrate the modern digital economy with corporate social responsibility for sustainable development. The aim of the research was to discover the main ways to increase corporate social responsibility in Romanian organizations in 3 key sub-areas of bio-economy. We also sought to identify and analyze the implementation level of fundamental principles and values of corporate social responsibility, strategic priorities and methods used by Romanian companies in the target group to strengthen it. Another objective of the research was to develop a hierarchy of strategic (economic, social and environmental) interests of the top managers of the analyzed organizations, reflecting the new business philosophy. The research tools used were: an online questionnaire, a semistructured interview with general managers and document analysis, that is: 10 organizational strategies, 60 bi-annual reports on corporate social responsibility and 30 budget executions from the last three years of activity of the organizations involved in the research. The data obtained were correlated and processed in Excel and SPSS. The novelty of the research consists in taking a systemic approach, from a managerial point of view, of corporate social responsibility in the field of bio-economy being the first applied research of its kind on the segment of medium-sized companies from three representative sub-domains of Romanian bio-economy.
\end{abstract}

Keywords: corporate social responsibility (CSR); bio-economy, sustainable development; strategic interests.

JEL Classification: O13; P16; Q57

\footnotetext{
* Corresponding author, Androniceanu Armenia - armenia.androniceanu@ man.ase.ro
} 


\section{Introduction}

Social responsibility is a preferred strategic option which is of increasing concern to the business environment because it has become a real source of creating and developing competitive advantage for organizations. Although social responsibility is not mandatory for companies, it has become an option that more and more managers consider to be a component of the organizational strategy that can ensure sustainable economic and social development, as accelerated growth competition on national and international markets are noticed. We are witnessing a change of economic paradigms and even economic models that integrate new defining elements for business success. Corporate Social Responsibility (CSR) is such an element, which has become an integral part of the sustainable economic and social development strategy and policy for an increasing number of multinational and transnational companies. In the international economic environment, managers are increasingly concerned to ensure balance between economic development, social and environmental policies. These significant changes take the form of specific strategic objectives and specific transparent activities that we find in organizational strategies and policies (Gerasimov et al., 2018; Gomme, 2018) Therefore, companies' strategic objectives integrate key elements of social responsibility. It can be stated that organizational managers are particularly interested in economic development, but that they are paying increasing attention to the social and environmental objectives. Thus, managers intend to develop their business on new social and environmental coordinates as a result of the integration of social responsibility elements (Kaasa, 2019). Recent studies (Dobrovik et al., 2018; Gablas et al., 2018; Kovacs and Kot, 2016) and surveys (Yameen, 2019; Derun and Mysaka, 2018; Meyer and Meyer, 2016) have certified that corporate social responsibility is for many multinational companies and transnational corporations an intrinsic component of their strategies and policies, and for others a clearly defined goal that, once achieved, can produce certain economic and image benefits. More and more teams of corporate managers understand that business growth does not mean only profit increase, that the growth is relative if it does not integrate CSR-defining elements. Professor Michael E. Porter stated that CSR "is an unavoidable priority for business leaders in every country and field" (Porter and Kramer, 2011, p.2).

CSR creates and strengthens the competitive advantage of the company in all areas. This change of economic paradigm is accompanied by the emergence and development of new economic areas and sub-domains where CSR will have to be progressively integrated. One of those is bio-economy, which is growing more and more as a cross-sector economic area, with many sub-domains. According to the literature (Galagedera, 2019), bio-economy is a branch of the economy in which the biological resources in the soil and sea and waste are exploited as raw materials for supplies, as food for animals and for industrial and energy production. At European level, this topic is supported by the European Commission's strategy and action plan known as "Innovating for Sustainable Growth: A Bioeconomy for Europe" (European Commission, 2018a, p. 2). European policies in this area are grounded on three main pillars: (1) the development of new technologies and processes for the bioeconomy; (2) the development of markets and competitiveness in the bio-economy sectors; (3) fostering collaboration between decision-makers and stakeholders. Statistics show that this area is evolving at an accelerated pace, in the European Union. At EU level, the turnover in this area is over 2000 billion Euros and has created over 22 million jobs in the following sub-domains: agriculture; fishing; forestry; food industry; chemical industry, biotechnology and energy industry (European Commission, 2018a). Progress is visible in 
Denmark; Finland; Germany, Ireland and the Netherlands, which are already implementing national bio-economy strategies industry (European Commission, 2018a). The European Commission supports the development of this area through its various sectoral programs. One of these is the Horizon 2020 Program, which has allocated over $€ 4.7$ billion for research in the areas of food security; sustainable agriculture; marine and maritime research and bio-economy industry (European Commission, 2018b). As a result of these investments in research and innovation for the development of bio-economy, the European Commission expects an added value of more than 10 Euros that will be generated in the bio-economy sectors for each invested euro by 2025 (European Commission, 2018a). In the international business environment, corporations from the United States, Canada, China and South Africa come to the fore in this field, as their governments have been implementing strategies and development programs in the bio-economy sub-fields for many years (Tvaronavičienè, 2019; Putra et al., 2019).

The field of bio-economy in Romania goes through a growth process, even if there is no clear, coherent and consistent strategic approach in place at national level (Androniceanu and Popescu, 2017; Mura et al., 2017). Statistics show that the sub-areas of bio-economy attract more and more new companies and thus an increase in the number of small and medium-sized firms in Romania is registered. Their contribution to the national GDP has been steadily increasing over the last decade. The economic growth potential they have in Romania is considerable if company managers identify business development opportunities in the area of bio-economy and are able to capitalize them in order to create and develop real, viable and sustainable competitive advantages. In this context, the integration of CSR into emerging organizations in the area of bio-economy represents a challenge for the business environment in Romania, in general, and for the organizations in the bio-economy sub-areas in particular. As shown by the literature (Cuervo-Cazurra, 2018; Chang et al., 2019; Turner et al., 2019), the issue of social responsibility is mainly approached in economically successful business areas and less in the new fields of the emerging economy (Klierova and Kutik, 2017), such as bio-economy (Gârdan et al., 2018; Vătămănescu et al., 2018). Addressing the CSR issue in the field of bio-economy in Romania represents a concern for very few researchers.

Our paper contributes to developing knowledge on how companies in the area of bioeconomy in Romania can achieve viable and sustainable development through the progressive integration of CSR elements into their strategies, policies and programs. Romania's development potential in the area of bio-economy is immense and that it is only a matter of time and of consistent government policy the business environment in this field needs to develop and successfully integrate the principles and the values of the CSR. Using a systematic and coherent research process, we aim to discover the main ways to increase the degree of CSR integration in the organizations in the area of bio-economy in Romania so that their solid and sustainable development is ensured in the medium and long term. From a theoretical point of view, the originality of our research endeavour consists in the systemic approach of corporate social responsibility issue and solid and sustainable development in the area of bio-economy. From a practical point of view, our research is the first applicative one conducted on medium-sized companies from three representative subareas of the Romanian bio-economy that addresses the CSR issue as an essential strategic option and identifies the main ways to strengthen these companies' capacity to create and develop competitive advantage in the medium and long term. 
The paper contains four main sections: state of art, research methodology, research results analysis and conclusions. Through this study, we demonstrate that, through its specific forms and activities, systematically and consistently integrated into the organizational strategy and policies, the CSR can become a key business success factor for the companies in the bio-economy area in Romania, which will capitalize on the major economic and social development potential our country has in this area.

\section{Social responsibility in the literature}

Based on a careful analysis of the literature of the last decades, we have discovered a paradox manifested in the international business environment in the field of bio-economy (Solesvik, 2017; Lisin et al., 2018; Hermawan and Gunardi, 2019). On the one hand, we can note a concentration of the economic development, in general, in different states and regions in the field of bio-economy, and on the other hand a segmentation of the international and regional markets can be observed in this field (Ararat, 2018; Liu et al., 2018). Decision makers at governmental, regional and international level are the factor that significantly influenced these economic manifestations (Poór et al., 2018). Large international and transnational corporations, as well as small and medium-sized companies in different countries have made significant changes in their business strategies due to the changes that have taken place in recent decades in stakeholders' behavior and their continuous concern to capitalize on national, regional and international development opportunities. Researchers (Malcolm, 2018; Nica et al., 2018; Morkūnas et al., 2018) have shown that over the past decades an increasing number of managers of major national, international and transnational companies have found that the CSR is at least as important to their businesses as growth in profits and turnover (Stoklasova, 2018). As a consequence, major changes have been made in their business philosophy, in the vision and mission of the companies to adapt them to the transformations of the ever-changing international economic and social environment (Drăgulănescu and Androniceanu, 2017). There are many theoretical and applicative researches on the CSR in the foreign literature (Barnett, 2019; Marti-Noguera, 2017), but most of them stand out for the unilateral approach to the issue, that is the development of the social side of the activity of the companies, which have mainly opted for the diversification of their social activities portfolio and less for the integration and change of their internal organization and their behavior in the business environment. Through our research, we demonstrate not only the need to thoroughly integrate the CSR principles and values into business strategies, but we also provide ways of action for the managers to capitalize on in order to develop their own business in the area of bio-economy. Even if the identified ways of action are based on a survey that included Romanian companies in the area of bio-economy, most of them can be successfully capitalized on by the majority of international and transnational corporations.

There is no standardized and accepted definition of the CSR in the Romanian literature and business environment, although the CSR is an acknowledged parameter in the European and international business environment. There are a number of Romanian authors who have approached the CSR in their papers (Dinu, 2011; Rădulescu, 2018) but most of them have limited themselves to highlighting and explaining the CSR forms of manifestation, the already established models, and its specific fundamental principles. Our contribution consists in discovering the progress made by the managers of three sub-domains of the Romanian bio-economy over the last two decades, namely: the industry that processes bio- 
resources; organic food industry and organic farming. In addition, the results of our research reveal the main practices of the CSR in the selected sub-domains, the current and future strategic priorities of the managers in this area and their economic, social and environmental interests in order to ensure viable and sustainable business development in a field with major potential in Romania.

According to the World Business Council for Sustainable Development (WBCSD, 2019, p. 1), the CSR is the "contribution made by an organization to sustainable economic development, based on stakeholders' collaboration: employees, local community, suppliers, partners, to improve quality of their lives in a modern developed society". The research results of a group of experts and observers from 99 ISO member countries (International Organization for Standardization, 2012) and from other over 40 specialised private-sector organizations have led to the elaboration of ISO standard 26000 on Social Responsibility (International Organization for Standardization, 2018). It was later supplemented by ISO standard 27000 (International Organization for Standardization, 2019) and ISO standard 28000 on Social Responsibility (ISO 28000 Standard, 2019). The problem is how can companies be determined to apply these standards, as long as the implementation depends exclusively on the desire and willingness of private sector managers and government policies? Our research provides answers to this question.

According to the European Commission's CSR Strategy (2011) and the National Strategy for Sustainable Development of Romania 2030 (2018), organizations should increase their social responsibility towards the environment and adapt their strategies and programs. The European Commission considers that the CSR is a phenomenon whereby companies voluntarily decide to contribute to a better society and a cleaner environment through the responsible integration of social and environmental issues alongside the economic ones. The European Commission places this topic in the context of sustainable development and considers that the CSR generates trust and attractiveness in the medium and long term, and associates the notion of the CSR with the "triple-bottom-line" concept (Comisia Europeană, 2018a) that is the three strategic objectives, namely: economic growth; environmental protection and social cohesion. Therefore, the CSR is ultimately only an option through which an organization, regardless of its size, ensures in a "standardized" manner the observance and implementation of CSR.

According to the European Commission (2018a), the business environment should take into account the following principles, values and requirements regarding the CSR: (1) protection of the environment and sustainable development of society in the interests of future generations by conserving resources, ensuring the health and safety of the population, reducing gender rights disparities, eliminating child exploitation, reducing poverty and increasing population education level; (2) developing the relations with their employees by creating civilized working conditions, adopting measures on employees' health and safety, providing incentives for personal and professional motivation of employees; (3) promoting honest attitudes towards the upstream and downstream business partners, namely suppliers and customers; (4) adopting transparent action directions regarding the company's activity towards employees, consumers, community and administration; (5) involvement in community life through effective participation, development, and targeted investment in this respect (Smékalová, 2018); (6) ensuring human rights, including the fundamental right to work and social integration; (7) respect for the rights of indigenous peoples and involvement in improving the quality of life; (8) applying anti-corruption measures, etc. 
In the recent decades, studies in the literature (Lăzăroiu, 2018; Mata, 2018; PuchetaMartinez and Lopez-Zamora, 2018; Da Silva et al., 2019) have shown that organizations implementing the CSR have had a number of advantages which have produced beneficial effects on their economic and financial results and their market image (Weber, 2019; Yoon and Chung, 2018). Through our research, we have found the opinion of the Romanian managers in the area of bio-economy about this issue and how can the CSR become an essential strategic option for the solid and sustainable development of companies in this field.

\section{Research methodology}

The research has started from the premise that the social responsibility of companies in any field can be seen as their commitment to contribute to a positive relationship with employees, the society and the environment, especially in cooperation with key stakeholders at local, regional, national and global. This positive relationship is achieved by maximizing the benefits and minimizing the risks of the company's operations, practices and products, building trust and transparency relationships with the public and key stakeholders. This research is an empirical one and is based on the investigation of representative organizations from three relevant sub-domains of bio-economy: the industry that processes bio-resources; organic food industry and organic farming. The choice was determined by the fact that these three sub-domains have recorded the largest contributions of the bio-economy field in the GDP of Romania in the last years. The survey was conducted between February 2018 and January 2019. 32 medium-sized organizations from the bio-economy sub-domains were contacted, but only managers from 10 organizations accepted to collaborate during the research process.

The aim of the research was to identify ways to increase Corporate Social Responsibility (CSR) in selected bio-economic organizations that will ensure their durable and sustainable development in the medium and long term. The main objectives of the research were: to know the state of integrating the CSR principles, values and norms in bio-economy into selected organizations; to identify the strategic priorities of the analyzed organizations in the following fields: economic, social and environmental; to know the main practices, methods, tools and standards used by bio-economy organizations to increase the CSR; to develop a hierarchy of causes of the strategic interests of the top managers of the analyzed organizations.

The research is representative at national level in the field of bio-economy, as the research base was made up of: 4 bio-resource industry companies; 3 companies in the bio-food industry and 3 other companies in the field of organic farming. They have had annual business growth over the past 3 years and have made significant contributions to the branch GDP. The organizations in the target group are medium sized, according to criteria established at European level, that are: (1) have less than 250 employees; (2) have a turnover of less than 50 million Euros; (3) have assets of less than 43 million Euros. All organizations included in the research have been engaged in CSR activities for many years, according to the information provided by each of them on their official websites. The target group comprised top managers, namely: general directors; production directors; economic directors, marketing directors, strategic planning and development directors. 49 top managers have participated in our research in total, which provides our research relevance 
and representativeness at national level. Sampling based on random selection of the companies in the targeted subdomains was used, thus enabling application of probability laws for estimating relevance and representativeness.

The research process has been carried out on three fundamental coordinates: (1) the CSR principles, values and norms, according to the United Nations and European legislation; (2) the CSR instruments, methods, standards, codes and certifications; (3) strategies, policies, programs of the organizations included in the research. Classical approaches to corporate social responsibility are largely based on models (Wartick and Cochran, 1985; Hemphill, 2004; Geva, 2008). In contrast, our research is based on meaningful and specific parameters designed to investigate corporate social responsibility from a double perspective: theoretical (principles, values, norms) and practical (managerial tools, standards, certifications, strategies, policies and programs.) Starting from these premises, the research hypotheses were as follows: (H1) If the CSR were a mandatory requirement for bioeconomy organizations, then the instruments and budgetary resources allocated to it would increase significantly; (H2) If stakeholders' requirements (managers, consumers, employees, business partners, suppliers, etc.) were better met due to the implementation of the CSR principles and values, the CSR would become an essential strategic priority of bioeconomy organizations; (H3) The limited financial resources allocated annually for CSR development are the cause of the low number of activities carried out and of specific instruments used.

The following research tools were used: the online questionnaire as the main data collection tool, which was processed using the specific applications in Word, Excel and SPSS; a semistructured interview conducted by phone and document analysis. The questionnaire is one of the most effective tools in setting up a representative, accurate and complete database that facilitates the testing and verification of research hypotheses. The questionnaire comprised of 12 questions and was filled in by 49 managers from the 10 companies from the target group. Data correlation and systematization was performed in an Excel file, in order to prepare them for statistical processing. For a more accurate and consistent analysis, the collected data was grouped according to certain research variables: the degree of organizational transparency; standard CSR and business ethics principles; the degree of CSR integration into the bio-economy organizational strategies, policies and programs. For some items in the questionnaire, a simple classification was made, that is according to one variable, while for others a combined classification was used, where two or more variables reflected a clearer situation. Most of the data was introduced and processed in SPSS (Statistical Package for Social Sciences). Thus, with the "Data Editor" editing window, the data was entered and the variables were integrated and correlated with the "Variable View" menu. The data has been processed and analyzed with the "Syntax Editor" function and represented using "Chart Editor". The results were displayed in the "Output Viewer".

The interview was a semi-structured one and was based on an interview guide, consisting of 4 relevant questions that would complement the results and help achieve the research objectives and verify the research hypotheses (Brance, 2018; Mihăilă et al., 2018; Yeo et al., 2018; Strielkowski, 2017). Document analysis was used to understand the content of organizational strategies, revenue and expenditure budgets over the past three years, which include the spending allocated to specific CSR activities. 10 strategies, 7 programs and policies, 30 extracts with CSR representative budget indicators and 30 annual activity reports of the bio-economy organizations involved in the research were consulted. The 
order in which the research tools were used was the following: document analysis, administration of questionnaires for the collection, correlation and systematization of data using statistical tools, followed by semi-structured interviews with general managers to complete the database and information needed to achieve the goal and objectives and to validate the research hypotheses.

\section{Research results and analysis}

Corporate Social Responsibility (CSR) has become a highly debated topic in recent years, which implies more obligations for companies: ethical behavior, the duty to support sustainable development, maximization of stakeholder profits and maintaining good relations with stakeholders (partners, customers, consumers, suppliers, shareholders, governmental and non-governmental bodies, etc.).

The bio-economy is a relatively new domain, and this is the first time an author approaches the CSR on a representative segment of organizations in three major sub-areas of the bioeconomy, which makes it of major interest in the literature. Addressing this topic in what bio-economy organizations are concerned has led to the identification of particularly interesting results, mainly because the development of this field is strongly marked by the ethics principles and values and social responsibility. Some of the results help establish the CSR implementation stage in the bio-economy organizations in Romania, and others reflect the current vision and prospects for sustainable strategic development of organizations in the field of bio-economy based on the diversification of CSR activities.

The research process has shown that most of the CSR principles established at European level based on those laid down by the United Nations are implemented in one way or another within the studied organizations. However, the intensity and frequency with which those are put into practice varies on a scale from 1 (minimum) to 5 (maximum). The results of our research show that the CSR principles are implemented in different forms and with varying levels of integration and representation ranging from 1 (minimum integration level) to 5 (maximum integration level) across the companies included in the study. Thus, we have found that the maximum level of CSR principles integration was 4 for $30 \%$ of the organizations, 3 for $40 \%, 2$ for $20 \%$, and 1 for $10 \%$ of them. A complete picture is presented below (Figure 1). On the one hand, these results show that the CSR principles are known and implemented with varying intensity and under different forms in all the analyzed companies in the field of bio-economy in Romania. On the other hand, it is shown that strong measures are needed to increase the representation of the CSR activities in these organizations up to level 5 (maximum).

In order to identify the managers' priorities in the decision-making process, we have considered 3 representative areas for the studied organizations, namely: the economic field (profit, turnover, market share, investments for the development of ecological products and services); the social field (human resources, organizational change and external social activities); the external environment (environmental protection, specialized certifications, environmental conservation activities).The main results are shown in the figure below (Figure 2). Research results show that in managers' opinion $70 \%$ of the decision-making priorities were and are related to the techno-economic field and only $20 \%$ of them are related to environmental protection, while $10 \%$ are priorities in the social field. 


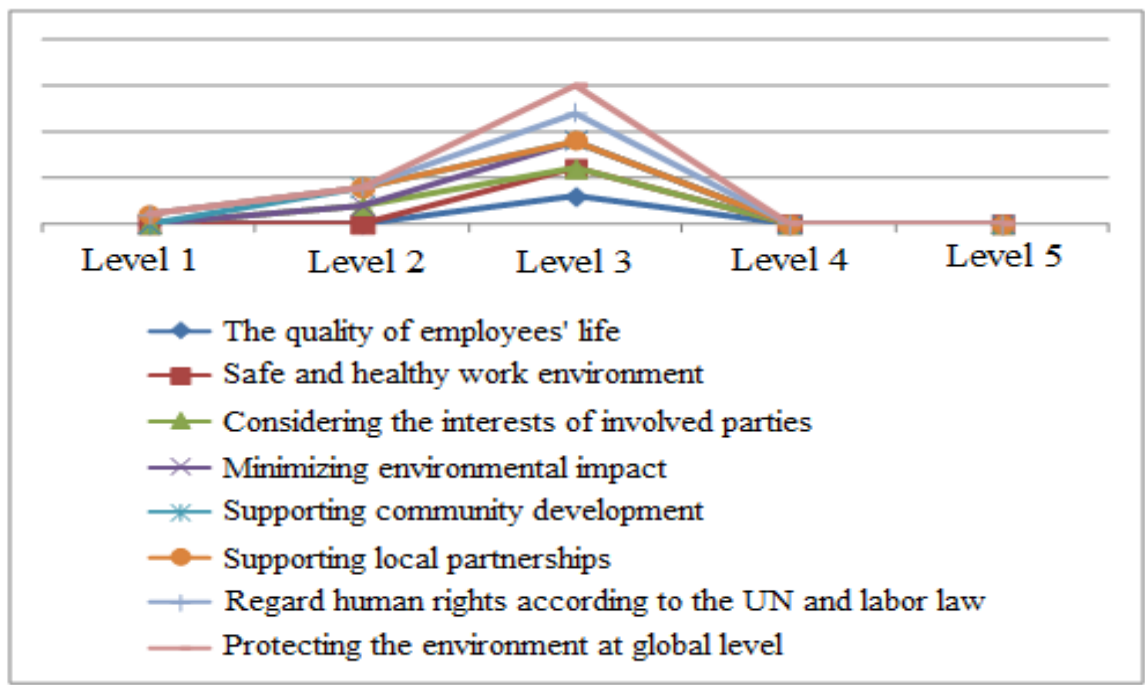

Figure no. 1: The state of CSR principles integration and the intensity of their implementation in the bio-economy organizations in Romania

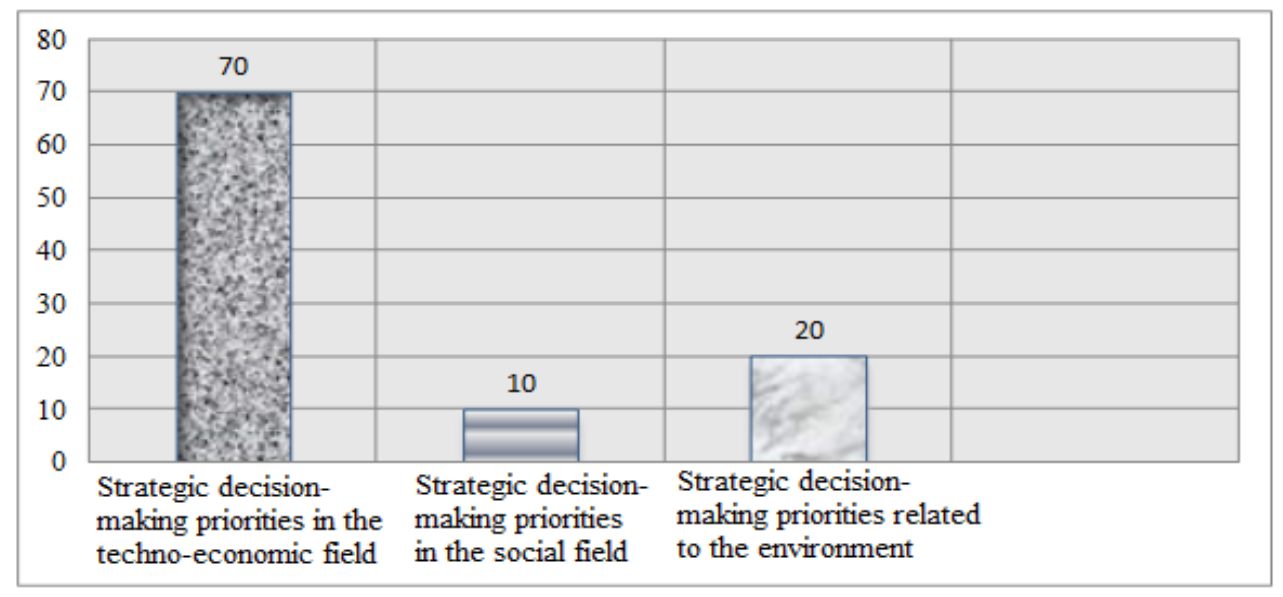

Figure no. 2: Strategic decision-making priorities grouped on the CSR representative domains over the last 5 years

These results show the clear and direct orientation of managers from Romanian companies in the field of bio-economy towards the development of new products and services and for sustainable economic performance reflected in clear strategic objectives. The fact that $30 \%$ of the strategic priorities of the managers in bio-economy refer to the external environment and the social area shows that these Romanian organizations have been and continue to be firmly concerned about the CSR and that this concern is placed by the managers in the group of priorities with an increasing trend. Using the research tools, we have identified managers' vision regarding their strategic priorities for the next 5 years. The main results are shown in the figure below (Figure 3). 


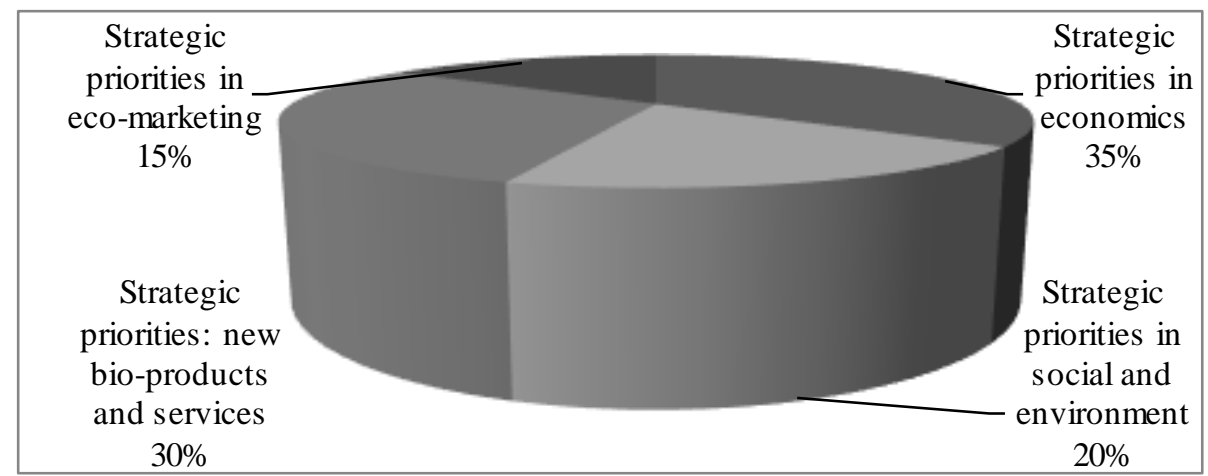

Figure no. 3: Strategic priorities of managers in the bio-economy field for the next 5 years

Research results show that managers' vision on the strategic priorities of the companies regarding the CSR changes easily, both in structure and weight. The above figure shows that the share of economic priorities $(35 \%)$ is diminishing over the next 5 years and the share of decisional priorities in the social, environmental $(20 \%)$ and marketing areas (15\%) is increasing compared to the present moment, while maintaining the issues related to technical and technological development of new bio products and services $(30 \%)$ in decision-making priorities area.

Another research objective has been to identify the main activities, methods, techniques and tools relevant to the CSR (Figure 4). The results show that there are a variety of activities and tools to support the CSR in companies in the field of bio-economy in Romania. However, only three organizations have a CSR Code, only 2 organizations have nonfinancial indicators for CSR assessment, and only one organization has a clear and consistent internal regulation on ethics and organizational behavior towards the environment and stakeholders and there is no function of manager for social responsibility in any of the organizations included in the research.

On the other hand, the research has revealed that standards have been implemented in all organizations, CSR certifications have been obtained, and annual CSR progress reports are being drafted. Through the research process we have identified areas of interest for the managers involved in our research. The obtained results have allowed us to outline a hierarchy of their current interests regarding the following aspects: (1) economic performance; (2) new organic products and services; (3) CSR management; (4) CSR marketing. To represent managers' interests, we used a Lickert scale with the following values: $4=$ maximum interest (priority); $3=$ high interest; $2=$ average interest; $1=$ minimum interest. The main results are presented below (Figure 5). The research results show that there is a variety of interests of the managers specialized in bio-economy, which are to be found in a system of objectives that relate directly to CSR. The ranking differences are strongly influenced by the specificity of the field under which the managerial function falls, which explains a normality situation, since each has specific performance indicators to achieve. 


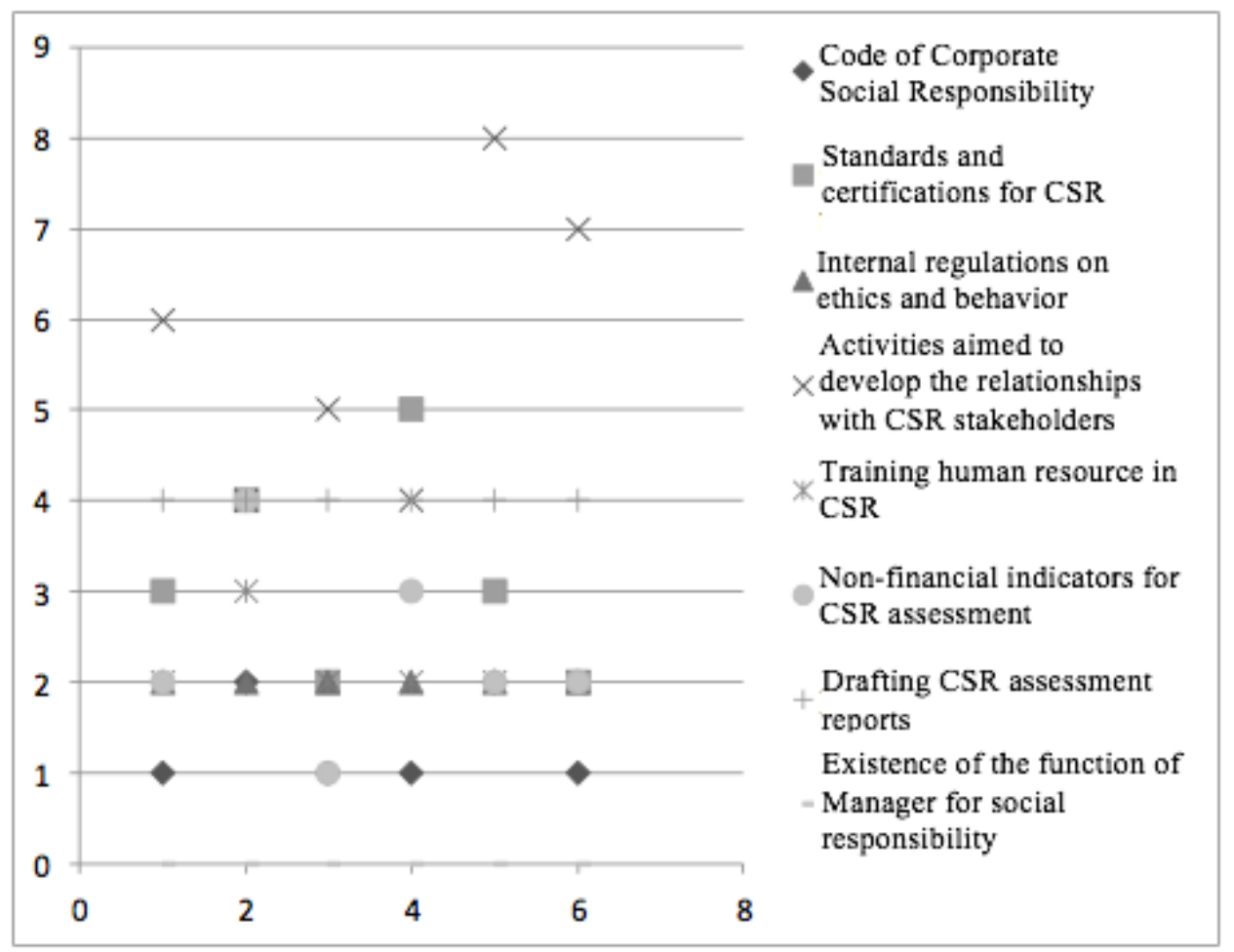

Figure no. 4: Matrix of CSR representative activities and tools in bio-economy companies

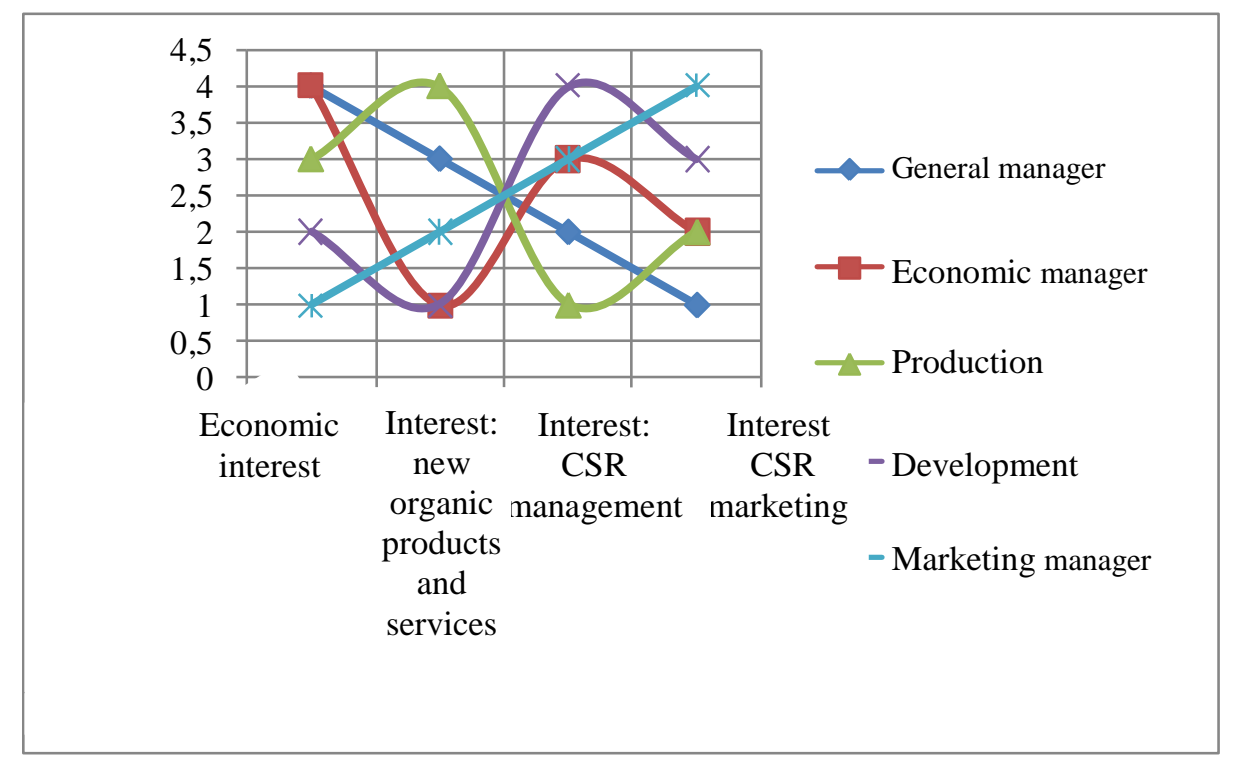

Figure no. 5: Ranking the interests of managers in the bio-economy field in Romania 
During the interviews with the general managers of the 10 organizations in the field of bioeconomy in Romania, we have identified the main responsibilities, which in their opinion significantly influence their decisions and managerial behavior. Those are: (1) the responsibility for strategic objectives; (b) the responsibility towards stakeholders; (c) the corporate social responsibility; (d) the environmental responsibility. After processing the results, we have found that all interviewed general managers (10) consider the responsibility for strategic objectives to be the most important one. Eight general managers positioned the responsibility towards stakeholders on the second place as importance, the corporate social responsibility on the third place, followed by the environmental responsibility, which has the lowest level of responsibility in their opinion. These results confirm that general managers continue to be focused on economic goals, and are aware that these draw major responsibilities when not achieved. Compared to the objectives on developing social responsibility and to the ones regarding environmental protection, economic objectives cannot be surpassed yet. Another interesting research result shows that three-quarters of the interviewed managers (38 managers) agree to support a budget increase for corporate social responsibility specific activities if the CSR becomes mandatory for all organizations. This result confirms the first research hypothesis. However, the remaining managers (11 managers) condition the increase of the CSR budget expenditure on the economic and financial results of their organizations. Most of the interviewed general managers (8) consider that the CSR can become a preferred strategic option in the coming years. Most of them ( 8 out of 10 ) would make some changes in their managerial philosophy if marketing research proves that more and more consumers of bioeconomy products are changing their lifestyle, requirements, expectations and needs of bio and organic products and services, and if suppliers and partners were stimulated by the investments made by bio-economy companies to use environmentally friendly raw materials and to deliver new competitive products and services. These results confirm the second research hypothesis which asserts that changes in stakeholders' requirements may lead to changes in the CSR approach within organizations, and thus it becomes a relevant strategic priority. In fact, $75 \%$ of the interviewed managers consider that the main cause for the low level of CSR development in their company is the limited financial resources, which did not allow them to develop the CSR as much as they wanted. This result confirms the third research hypothesis.

The purpose of this research was to identify the main ways of enhancing the CSR in Romanian organizations in the field of bio-economy. For this we have interrogated each manager (49 managers) through the questionnaire and also 10 general managers through interviews performed by phone. The results are particularly interesting and highlight the agreement or disagreement of the general managers with the forms of CSR development recommended in the literature. An overview is presented below (Figure 6).

The analysis of the strategies of the companies included in the target group has shown that CSR specific activities are represented in these documents at a rate of $20 \%$, which shows the need to increase this percentage. This fact has been admitted as necessary and appropriate by the majority of the managers involved in the research. The analysis of the 30 budget executions and of the 30 annual activity reports of the target group companies has revealed that 4 organizations have allocated less than $3 \%$ of their profit for CSR development activities, while 6 organizations have allocated between $3 \%-8 \%$ of their profit for specific CSR development activities. Percentages are low compared to the budget allocations of Western medium-sized companies in this field (between 10\% and 25\%). 


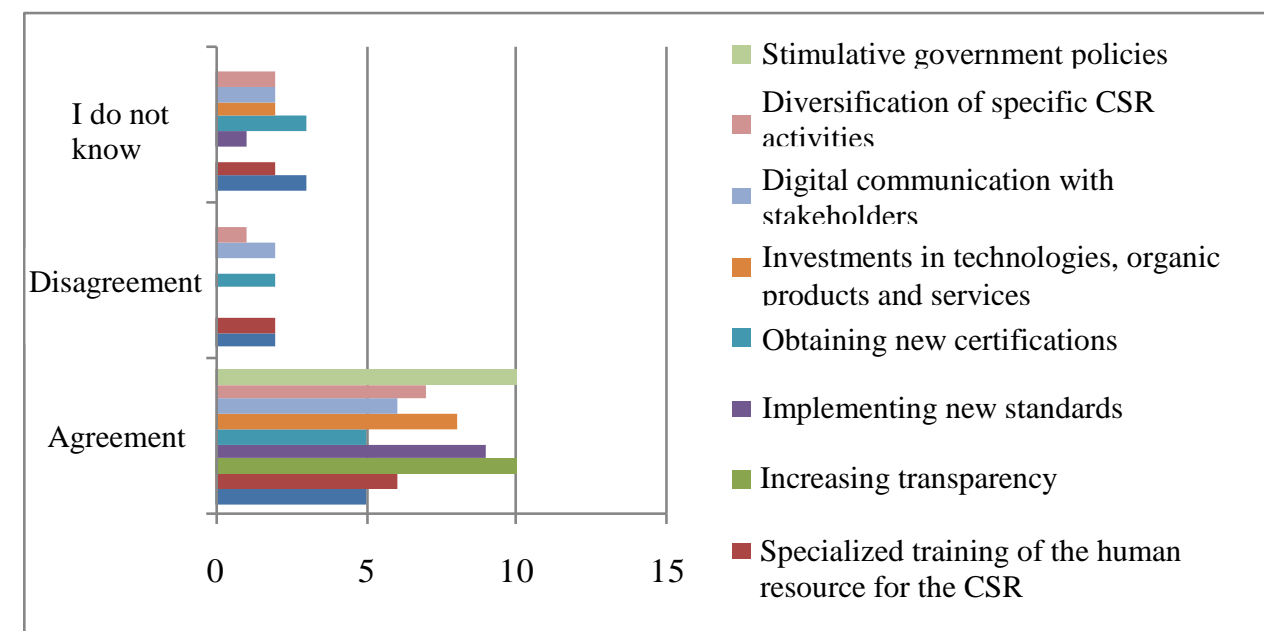

Figure no. 6: The main ways to enhance the CSR in the opinion of managers from companies in the field of bio-economy in Romania

\section{Conclusions}

The research has led to interesting results that help the reader discover the state of CSR implementation in bio-economy organizations in Romania. Thus, specific forms of implementation and prospects for the development of standardization and certification systems of the CSR in Romanian companies were identified. The research has also highlighted the strategic priorities for CSR development under the conditions of major changes in Romania in all sub-areas of the bio-economy. An important contribution of the research consists in identifying ways of growth and diversification of CSR activities in bioeconomy organizations as a derivate of aspects reconsideration in what environment and stakeholders of sustainable business development are concerned. The research has also highlighted that a significant, even essential, shift in the prioritization of managers' business interests is taking place. The majority of those involved in our research have expressed maximum availability for the CSR integration in all the stages of the management and execution processes of products and services in the area of bio-economy over the next five years. These aspects are particularly relevant because most research on the CSR in recent years has shown that managers' attention is focused on economic and financial performance.

The main limitation of this research is the small number of sub-domains investigated in the field of bio-economy (3 out of 11 sub-domains recognized at European level). The research will be extended to the other sub-domains of the bio-economy too and large and small companies in Romania will be integrated into the target group. Another research direction is performing a comparative study on the impact of the CSR implementation in the field of bio-economy in the different European Union member states. 


\section{References}

Androniceanu, A. and Popescu, C.R., 2017. An inclusive model for an effective development of the renewable energies public sector. Administratie si Management Public, 28, pp.81-96.

Ararat, M., Colpan, A.M. and Matten, D., 2018. Business groups and corporate responsibility for the public good. Journal of Business Ethics, 153(4), pp. 911-929.

Barnett, M.L., 2019. The business case for corporate social responsibility a critique and an indirect path forward. Business \& Society, 58(1), pp.167-190.

Brance, I., 2018. Questionnaire design, how to plan, structure and write survey material for effective market research. London: Kogan Page Limited.

Chang, DR., Jang, J., Lee, H. and Nam, M., 2019. The effects of power on consumers' evaluation of a luxury brand's corporate social responsibility. Psychology \& Marketing, 36(1), pp.72-83.

Comisia Europeană, 2018a. O bioeconomie durabilă pentru Europa: consolidarea legăturilor dintre economie, societate și mediu. [online] Available at: <http://www.cdep.ro/afaceri_europene/CE/2018/COM_2018_673_RO_ACTE_f.pdf> [Accessed 7 January 2019].

Comisia Europeană, 2018b. Corporate social responsibility in practice. [online]. Available at: <https://www.ohchr.org/Documents/Publications/GuidingPrinciplesBusinessHR_EN .pdf> [Accessed 9 December 2018].

Cuervo-Cazurra, A., 2018. The evolution of business groups' corporate social responsibility. Journal of Business Ethics, 153(4), pp.997-1016.

Da Silva, A., Martins-Silva, P.D., Vasconcelos, K.C.D., da Silva, V.C., de Brito, S.L.M.S. and Monteiro, J.M.R., 2019. Sustainability and corporate social responsibility in the opinion of undergraduate students in management programs: Between the concrete and the abstract. Journal of Cleaner Production, 207, pp. 600-617.

Derun, I. and Mysaka, H., 2018. Stakeholder perception of financial performance in corporate reputation formation. Journal of International Studies, 11(3), pp.112-123.

Dinu, V., 2011. Responsabilitatea socială corporativă - oportunitate de reconciliere a intereselor economice cu cele sociale și de mediu. Amfiteatru Economic, 12(29), pp.6-7.

Dobrovic, J., Gallo, P., Mihalcova, B., Stofova, L. and Szaryszova, P., 2018. Competitiveness measurement in terms of the Europe 2020 Strategy. Journal of Competitiveness, 10(4), pp.21-37.

Drăgulănescu, I.V. and Androniceanu, A., 2017. Risk management in global sourcing. $21^{\text {st }}$ International Conference on Economic and Social Development, 18-19 May, Belgrad, Serbia, pp. 695-702.

Gablas, B., Ruzicky, E. and Ondrouchova, M., 2018. The change in management style during the course of a project from the classical to the agile approach. Journal of Competitiveness, 10(4), pp.38-53.

Galagedera, D.U.A., 2019. Modelling social responsibility in mutual fund performance appraisal: A two-stage data envelopment analysis model with non-discretionary first stage output. European Journal of Operational Research, 273(1), pp.376-389. 
Gerasimov, B.N., Vasyaycheva, V.A. and Gerasimov, K.B., 2018. Identification of the factors of competitiveness of industrial company based on the module approach, Entrepreneurship and Sustainability Issues, 6(2), pp.677-691.

Geva, A., 2008. Three models of corporate social responsibility: interrelationships between theory, research, and practice. Business and Society Review, 113, pp.1-41.

Gomme, J., 2018. Entering a new era of human rights transparency. [online] Available at: <https://www.wbcsd.org/Programs/People/Social-Impact/Human-

Rights/News/Entering-a-new-era-of-human-rights-transparency> [Accessed 17 December 2018].

Hemphill, T.A., 2004. Corporate citizenship: the case for a new corporate governance model. Business and Society Review, 109(3), pp.339-361.

Hermawan, A. and Gunardi, A., 2019. Motivation for disclosure of corporate social responsibility: evidence from banking industry in Indonesia. Entrepreneurship and Sustainability Issues, 6(3), pp.1097-1106.

International Organization for Standardization, 2018. Social responsibility-schematic overview of ISO 26000. [online] Available at: <http://www.iso.org/publication /PUB100260> [Accessed 17 March 2019].

International Organization for Standardization, 2019. Information security management systems - overview and Vocabulary. [online] Available at: <http://www.iso27001 security.com/html/27000.html> [Accessed 17 March 2019].

International Organization for Standardization, 2019. ISO 28000 Standard: Supply Chain Security Certification, [online] Available at: <http://www.sgs.com/ISO-28000-supplychain-security-management-systems> [Accessed 17 March 2019].

Kaasa, A., 2019. Determinants of individual-level social capital: Culture and personal values. Journal of International Studies, 12(1), pp.9-32.

Klierova, M. and Kutik, J., 2017. One stop government - strategy of public services for citizens and businesses in Slovakia. Administratie si Management Public, 28, pp.66-80.

Kovacs, G. and Kot, S. 2016. New logistics and production trends as the effect of global economy changes. Polish Journal of Management Studies, 14(2), pp.115-126.

Lăzăroiu, G., 2018. Participation environments, collective identities, and online political behavior: the role of media technologies for social protest campaigns. Geopolitics, History, and International Relations, 10(2), pp.58-63.

Lisin, E., Kurdiukova, G., Ketoeva, N. and Katina, J., 2018. Sustainability issues of territorial power systems in market conditions. Entrepreneurship and Sustainability Issues, 6(2), pp.1041-1052.

Liu, Y.W., Gulzar, M.A., Zhang, Z.G. and Yang, Q.X., 2018. Do interaction and education moderate top management team age heterogeneity and corporate social responsibility? Social Behavior and Personality, 46(12), pp.2063-2080.

Malcolm, G.-H., 2018. Collective movements, digital activism, and protest events: the effectiveness of social media Cconcerning the organization of large-scale political participation. Geopolitics, History, and International Relations, 10(2), pp.64-69.

Marti-Noguera, J.J.; Puerta-Lopera, I.C. and Rojas-Roman, P., 2017. About the social responsibility of universities. Revista Colombiana de Ciencias Sociales, 8(2), pp.302-309. 
Mata, F.P., 2018. The social responsability of stakeholders in advertising: the need for an ethical commitment in advertising industry. Methaodos - Revista de Ciencias Sociales, 6(1), pp.38-51.

Meyer, N., Meyer, D.F., 2016. The relationship between the creation of an enabling environment and economic development: a comparative analysis of management at local government sphere. Polish Journal of Management Studies, 14 (2), pp. 150-160.

Mihăilă, R., Gregova, E., Janoskova, K., Kolencik, J. and Arsene, A.M., 2018. The instrumental function of gendered citizenship and symbolic politics in the social construction of labor rights for migrants. Journal of Research in Gender Studies, 8(2), pp.127-136.

Morkūnas, M., Volkov, A., Bilan, Y. and Raišienè, A.G., 2018. The role of government in forming agricultural policy: economic resilience measuring index exploited. Administrație și Management Public, 31, pp.111-131.

Mura, L., Daňová, M., Vavrek, R. and Dúbravská, M., 2017. Economic freedom classification of its level and impact on the economic security. AD ALTA-Journal of Interdisciplinary Research, 7(2), pp.154-157.

Nica, E., Manole, C., and Stan, C. I., 2018. A laborless society? How highly automated environments and breakthroughs in artificial intelligence bring about innovative kinds of skills and employment disruptions, altering the nature of business process and affecting the path of economic growth. Journal of Self-Governance and Management Economics, 6(4), pp.25-30.

Organizația Internaţională de Standardizare, 2012. Economic benefits of standards. [online] Available at: <https://www.iso.org/files/live/sites/isoorg/files/news/magazine/ISO\%20 Focus+\%20(2010-2013)/en/2011/ISO\%20Focus+,\%20March\%202011.pdf.> [Accessed 9 December 2018]

Poór, J., Juhász, T., Machová, R., Bencsik, A. and Bilan, S., 2018. Knowledge management in human resource management: Foreign-owned subsidiaries' practices in four CEE countries. Journal of International Studies, 11(3), pp.295-308.

Porter, M.E. and Kramer, M.R., 2011. The big idea: creating shared value, rethinking capitalism. Harvard Business Review, January-February, pp.1-6. [online] Available at: <http://hbr.org/2011/01/the-big-idea-creating-shared-value/ar/pr> [Accessed 14 March 2019].

Pucheta-Martinez, M.C. and Lopez-Zamora, B., 2018. Corporate social responsibility strategies of Spanish listed firms and controlling shareholders' representatives. Organization \& Environment, 31(4), pp.339-359.

Putra, B.A., Darwis and Burhanuddin. 2019. ASEAN Political-Security Community: Challenges of establishing regional security in the Southeast Asia. Journal of International Studies, 12(1), 33-49.

Rădulescu, A., 2018. Users' social trust of sharing data with companies: online privacy protection behavior, customer perceived value, and Continuous usage intention. Contemporary Readings in Law and Social Justice, 10(1), pp.137-143.

Smékalová, L., 2018. Evaluating the cohesion policy: targeting of disadvantaged municipalities. Administratie si Management Public, 31, pp.143-154. 
Solesvik, M., 2017. The triple helix model for regional development and innovation: context of nordic countries. Forum Scientiae Oeconomia, 5(4), pp.5-21.

Stoklasová, R., 2018. Econometric analysis of SMEs in Eurozone. Forum Scientiae Oeconomia, 6(1), pp.19-30.

Strielkowski, W., 2017. Social and economic implications for the smart grids of the future. Economics and Sociology, 10(1), pp.310-318.

Turner, M.R., McIntosh, T., Reid, S.W. and Buckley, M.R., 2019. Corporate implementation of socially controversial CSR initiatives: Implications for human resource management. Human Resource Management Review, 29(1), pp.125-136.

Tvaronavičienè, M., 2019. Insights into global trends of capital flows' peculiarities: emerging leadership of China. Administratie si Management Public, (32), pp. 6-17.

Yeo, A.C.-M., Carter, S., and Chezulhaimee, N.A., 2018. Corporate social responsibility intervention: a catalyst to small-medium enterprise employee engagement. Psychosociological Issues in Human Resource Management, 6(1), pp.38-62.

Yameen, M., Farhan, N.H. and Tabash, M.I., 2019. The impact of corporate governance practices on firm's performance: an empirical evidence from Indian tourism sector. Journal of International Studies, 12(1), pp.208-228.

Yoon, B. and Chung, Y.S., 2018. The effects of corporate social responsibility on firm performance: A stakeholder approach. Journal of hospitality and tourism management, 37, pp.89-96.

Wartick, S.L. and Cochran, P.L., 1985. The evolution of the corporate social performance model. Academy of Management Review, 10(4), pp.758-769.

Weber, J.L., 2019. Corporate social responsibility disclosure level, external assurance and cost of equity capital. Journal of Financial Reporting and Accounting, 16(4), pp. 694-724.

World Business Council for Sustainable Development, 2019. Insider perspective: The United Nations Forum on business and human rights. [online] Available at: <https://www.wbcsd.org/Overview/News-Insights/Insider-perspective/The-UnitedNations-Forum-on-Business-and-Human-Rights> [Accessed 7 January 2019]. 